\title{
Nitrate Uptake in the Halotolerant Cyanobacterium Aphanothece halophytica is energy-dependent driven by $\Delta \mathrm{pH}$
}

\author{
Aran Incharoensakdi* and Surasak Laloknam \\ Department of Biochemistry and Program of Biotechnology, Faculty of Science, Chulalongkorn University, Bangkok 10330, Thailand
}

Received 4 March 2005, Accepted 4 April 2005

The energetics of nitrate uptake by intact cells of the halotolerant cyanobacterium Aphanothece halophytica were investigated. Nitrate uptake was inhibited by various protonophores suggesting the coupling of nitrate uptake to the proton motive force. An artificially-generated $\mathrm{pH}$ gradient across the membrane $(\Delta \mathrm{pH})$ caused an increase of nitrate uptake. In contrast, the suppression of $\Delta \mathrm{pH}$ resulted in a decrease of nitrate uptake. The increase of external $\mathrm{pH}$ also resulted in an enhancement of nitrate uptake. The generation of the electrical potential across the membrane $(\Delta \psi)$ resulted in no elevation of the rate of nitrate uptake. On the other hand, the valinomycin-mediated dissipation of $\Delta \psi$ caused no depression of the rate of nitrate uptake. Thus, it is unlikely that $\Delta \psi$ participated in the energization of the uptake of nitrate. However, $\mathrm{Na}^{+}$-gradient across the membrane was suggested to play a role in nitrate uptake since monensin which collapses $\mathrm{Na}^{+}$-gradient strongly inhibited nitrate uptake. Exogenously added glucose and lactate stimulated nitrate uptake in the starved cells. $N, N^{\prime}-$ dicyclohexylcarbodiimide, an inhibitor of ATPase, could also inhibit nitrate uptake suggesting that ATP hydrolysis was required for nitrate uptake. All these results indicate that nitrate uptake in A. halophytica is ATP-dependent, driven by $\Delta \mathrm{pH}$ and $\mathrm{Na}^{+}$-gradient.

Keywords: Aphanothece halophytica, Cyanobacteria, Nitrate uptake, $\Delta \mathrm{pH}$, Proton motive force

\section{Introduction}

Cyanobacteria are photoautotrophic organisms that perform oxygen-evolving photosynthesis typical of higher plant systems using carbon dioxide as carbon source. All cyanobacteria are capable of utilizing nitrate as their sole nitrogen source.

\footnotetext{
* To whom correspondence should be addressed.

Tel: 662-2185419; Fax: 662-2185418

E-mail: iaran@sc.chula.ac.th
}

However, cyanobacteria usually utilize reduced nitrogen sources such as ammonia and urea in preference to nitrate (Flores and Herrero, 1994). The active transport of nitrate is thought to be the rate-limiting step for nitrate assimilation. After entry into the cell, nitrate is reduced to ammonium by the sequential action of nitrate reductase and nitrite reductase before being fixed into amide nitrogen of glutamine.

Aphanothece halophytica is the halotolerant cyanobacterium able to grow under a wide range of $\mathrm{NaCl}$ concentrations up to 3 M (Takabe et al., 1988). The successful strategies used by $A$. halophytica to cope with high external salinity include the accumulation of glycine betaine (Incharoensakdi and Wutipraditkul, 1999), and the extrusion of $\mathrm{Na}^{+}$mediated by an $\mathrm{Na}^{+} / \mathrm{H}^{+}$antiporter (Waditee et al., 2001). Carbon assimilation in A. halophytica also increased in response to salt stress (Takabe et al., 1988). On the other hand, nitrate assimilation with respect to the uptake of nitrate was recently shown to decrease in A. halophytica grown under salt-stress condition (Incharoensakdi and Wangsupa, 2003). In addition, it was also shown that nitrate uptake is $\mathrm{Na}^{+}$-dependent in cells grown under both non-stress and salt-stress conditions.

Nitrate uptake has been studied extensively in plants (Crawford and Glass, 1998). Three kinetically distinct nitrate transport systems are found in plant roots, i. e. two high affinity transport systems (HATS), one is constitutive and the other is inducible, and the third is constitutive low affinity transport system (LATS). The energy for nitrate uptake in plants is provided by the proton gradient or the proton motive force (Crawford and Glass, 1998) and nitrate uptake is mediated by $2 \mathrm{H}^{+} / 1 \mathrm{NO}_{3}{ }^{-}$symport mechanism (Meharg and Blatt, 1995; Miller and Smith, 1996). Only recently, nitrate uptake in the marine higher plant Zostera marina L. was shown to be mediated by a high affinity $\mathrm{Na}^{+}$-symport system (Garcia-Sanchez et al., 2000). Until now the study on the nitrate uptake in cyanobacteria with regard to energy requirement has been very scarce. Most studies in cyanobacteria have dealt mainly with the characterization and regulation of genes for nitrate assimilation (Flores and Herrero, 1994).

In the present study we were able to demonstrate that 
nitrate uptake in A. halophytica was driven by $\Delta \mathrm{pH}$ term of the proton motive force and that sodium motive force might also be involved in nitrate uptake.

\section{Materials and Methods}

Organism and culture Aphanothece halophytica was grown photoautotrophically in BG 11 medium supplemented with $18 \mathrm{mM}$ $\mathrm{NaNO}_{3}$ as described previously (Incharoensakdi and Waditee, 2000). A slight modification was made in which molybdenum in the medium was replaced with tungsten to induce the cells to synthesize nitrate reductase in an inactive form (Lara et al., 1987). Cells were grown in a $250-\mathrm{mL}$ flask containing $100 \mathrm{~mL}$ medium on a rotary shaker at $30^{\circ} \mathrm{C}$ without $\mathrm{CO}_{2}$ supplementation. Continuous illumination was provided by cool white fluorescent lamps at an irradiance of $60 \mu \mathrm{Em}^{-2} \mathrm{~s}^{-1}$. The concentration of $\mathrm{NaCl}$ in the medium was adjusted to $0.5 \mathrm{M}$.

Assay of nitrate uptake Log-phase cells were washed twice in $25 \mathrm{mM}$ Hepes-KOH buffer, pH 8.2, containing $10 \mathrm{mM} \mathrm{NaHCO}_{3}$ and $0.5 \mathrm{M}$ sorbitol, and were suspended in the same buffer at a chlorophyll (Chl) concentration of $25 \mu \mathrm{g} / \mathrm{mL}$ determined as described by Mackinney (1941). The reaction was started by the addition of $100 \mu \mathrm{M} \mathrm{NaNO}$ to the suspension and kept at $30^{\circ} \mathrm{C}$ in the light with an irradiance of $60 \mu \mathrm{Em}^{-2} \mathrm{~s}^{-1}$. Samples were removed at various time intervals and rapidly filtered through a $0.45 \mu \mathrm{m}$ membrane filter. The nitrate content remaining in the filtrate was determined by anion-exchange high performance liquid chromatography (Hypersil-10 Sax column, $250 \mathrm{~mm} \times 4.6 \mathrm{~mm}$ ) (Incharoensakdi and Wangsupa, 2003).

EDTA-treated cells Prior to incubation with monensin or valinomycin, the cells were incubated $15 \mathrm{~min}$ at $30^{\circ} \mathrm{C}$ in $100 \mathrm{mM}$ Tris-HCl $\mathrm{pH} 7.0$, supplemented with $1 \mathrm{mM}$ EDTA, and washed twice with the assay buffer in absence of EDTA. This treatment suppresses impermeability of cell membrane for these ionophores (Joshi et al., 1989).

Uptake assays in absence of potassium were performed using $100 \mathrm{mM}$ Tris-maleate buffer for $\mathrm{pH} 5.5$ and $100 \mathrm{mM}$ Tris-HCl buffer for $\mathrm{pH} 7.0$ or 8.2. Assays having potassium in the uptake medium were performed with $100 \mathrm{mM}$ potassium phosphate buffer for the three $\mathrm{pH}$ values.

Artificial generation and suppression of $\mathrm{pH}$ gradient $(\Delta \mathrm{pH})$ and membrane potential $(\Delta \psi)$ The $\Delta \mathrm{pH}$ was generated in acetate loaded cells $(80 \mathrm{mM}$ potassium acetate buffer at $\mathrm{pH} 5.5$ or 7.0$)$ (Allende et al., 2000), the supernatant was then removed and cells were diluted in $100 \mathrm{mM}$ Tris-maleate buffer (pH 5.5) or Tris-HCl buffer ( $\mathrm{pH} 7.0) . \Delta \mathrm{pH}$ was generated at $\mathrm{pH} 8.2$ in ethanolamine- $\mathrm{HCl}$ loaded cells instead of acetate loaded cells. The $\Delta \mathrm{pH}$ was suppressed using $80 \mathrm{mM}$ potassium acetate buffer at $\mathrm{pH} 5.5$ and $\mathrm{pH}$ 7.0, $80 \mathrm{mM}$ ethanolamine- $\mathrm{HCl}$ buffer at $\mathrm{pH} 8.2$ (Booth, 1985; Allende et al., 2000).

The generation and suppression of $\Delta \psi$ were done according to Allende et al., (2000). The artificial $\Delta \psi$ was imposed using $20 \mathrm{mM}$ $\mathrm{KSCN}$ or $3 \mu \mathrm{M}$ valinomycin with EDTA-treated cells in absence of
$\mathrm{K}^{+}$using $100 \mathrm{mM}$ Tris-maleate buffer (pH 5.5) or $100 \mathrm{mM}$ Tris$\mathrm{HCl}$ buffer ( $\mathrm{pH} 7.0$ or 8.2 ). The $\Delta \psi$ term was suppressed using $3 \mu \mathrm{M}$ valinomycin and EDTA-treated cells with $100 \mathrm{mM}$ potassium phosphate buffer for the three $\mathrm{pH}$ values.

\section{Results}

Energy-dependent nitrate uptake To determine whether nitrate uptake was energy-dependent, the effects of some inhibitors on nitrate uptake were investigated. As shown in Table1 transport uncouplers such as carbonyl cyanide mchlorophenylhydrazone (CCCP), 2, 4-dinitrophenol (DNP), and gramicidin D, which dissipate proton motive force (Kroll and Booth, 1981), could effectively inhibit nitrate uptake to a similar extent by about $70-75 \%$. Sodium azide, an inhibitor of cytochrome oxidase, which also dissipates proton motive force strongly inhibited the uptake. All these results indicate that nitrate uptake by $A$. halophytica was energized by proton motive force. Interestingly, monensin which collapses $\mathrm{Na}^{+}-$ electrochemical gradient also caused drastic inhibition of nitrate uptake. $N, N$-dicyclohexylcarbodiimide (DCCD), an ATPase inhibitor, also inhibited nitrate uptake with strong inhibition being observed at $100 \mu \mathrm{M}$ DCCD. This suggests the involvement of ATP hydrolysis in the uptake of nitrate.

Effect of different energy sources on nitrate uptake To assess the roles of ATP and proton motive force in energizing the uptake of nitrate, A. halophytica cells were starved to deplete endogenous energy sources. Nitrate uptake was then monitored after reenergization with glucose or lactate (Table 2). Both glucose and lactate could energize the uptake of nitrate in the starved cells. These results indicate that nitrate uptake is an energy-dependent process and depends on the

Table 1. Effect of metabolic inhibitors on nitrate uptake ${ }^{a}$

\begin{tabular}{ccc}
\hline Inhibitor & Concentration & Nitrate uptake (\%) \\
\hline None & & 100 \\
& $20 \mu \mathrm{M}$ & 50 \\
CCCP & $40 \mu \mathrm{M}$ & 26 \\
& $1 \mathrm{mM}$ & 60 \\
DNP & $2 \mathrm{mM}$ & 28 \\
& $10 \mu \mathrm{g} / \mathrm{ml}$ & 34 \\
Gramicidin D & $20 \mu \mathrm{g} / \mathrm{ml}$ & 24 \\
& $10 \mathrm{mM}$ & 50 \\
NaN $_{3}$ & $30 \mathrm{mM}$ & 16 \\
& $20 \mu \mathrm{M}$ & 46 \\
Monensin & $30 \mu \mathrm{M}$ & 25 \\
& $40 \mu \mathrm{M}$ & 60 \\
DCCD & $100 \mu \mathrm{M}$ & 35 \\
& $15 \mathrm{mM}$ & 101 \\
KF & $30 \mathrm{mM}$ & 100 \\
\hline
\end{tabular}

${ }^{a}$ Cells were preincubated with inhibitors in the dark for $30 \mathrm{~min}$ before the addition of $100 \mu \mathrm{M} \mathrm{NaNO}$ 位 initiate the uptake as described in Materials and Methods. 
Table 2. Effect of energy sources on nitrate uptake ${ }^{a}$

\begin{tabular}{cc}
\hline Addition & Nitrate uptake (\%) \\
\hline None & 100 \\
Glucose $(20 \mathrm{mM})$ & 128 \\
Lactate $(10 \mathrm{mM})$ & 116 \\
KCN $(20 \mathrm{mM})$ & 24 \\
Glucose $+\mathrm{KCN}$ & 28 \\
Lactate $+\mathrm{KCN}$ & 33 \\
\hline
\end{tabular}

${ }^{a}$ Cells were starved by suspending cells in the growth medium lacking carbon and nitrogen source in the dark for $24 \mathrm{~h}$. The starved cells were then assayed for nitrate uptake in the presence of different energy sources or respiratory inhibitor. Starved cells were preincubated with the tested compound(s) in the dark for $30 \mathrm{~min}$ before the addition of $100 \mu \mathrm{M} \mathrm{NaNO}$ to initiate the uptake as described in Materials and Methods.

proton motive force. The respiratory inhibitor, $\mathrm{KCN}$, strongly inhibited nitrate uptake, either alone or together with glucose or lactate.

Role of $\Delta \mathrm{pH}$ on nitrate uptake The proton motive force, which is known to energize a number of active transport processes, has two components namely the electrical potential $(\Delta \psi)$ and the chemical hydrogen ion concentration gradient $(\Delta \mathrm{pH})$ across the membrane. To test whether $\Delta \mathrm{pH}$ played an energetic role in the uptake of nitrate, we artificially generated $\mathrm{pH}$ as well as suppressed $\Delta \mathrm{pH}$ and followed the extent of nitrate uptake at three different $\mathrm{pHs}$. At $\mathrm{pH} 5.5, \Delta \mathrm{pH}$ was generated by diluting acetate-loaded cells ( $\mathrm{pH} 5.5$ ) into a solution containing Tris-maleate as a less permeable anion ( $\mathrm{pH}$ 5.5). This would cause the diffusion of acetate across the membrane in its protonated form. As shown in Fig. 1A, an increase in nitrate uptake by such treatment was clearly evident. In contrast, the suppression of $\Delta \mathrm{pH}$ imposed with 80 $\mathrm{mM}$ potassium acetate buffer resulted in a reduction of nitrate uptake. Similar results were obtained when the experiments were done at pH 7.0 (Fig. 1B) and pH 8.2 (Fig. 1C).
Role of $\Delta \psi$ on nitrate uptake at different pHs To investigate whether another component of the proton motive force, $\Delta \psi$, contributed the driving force for nitrate uptake, we artificially generated $\Delta \psi$ either by supplementation of KSCN or by valinomycin in the absence of $\mathrm{K}^{+}$and then monitored the uptake of nitrate. Table 3 shows that at the three $\mathrm{pHs}$ tested, the rates of nitrate uptake did not increase under the influence of $\Delta \psi$ by the addition of $20 \mathrm{mM} \mathrm{KSCN}$ to the medium (cell inside is more negative than the control). Indeed, a slight decrease of nitrate uptake was observed. Likewise, the generation of $\Delta \psi$ by an imposition of an outwardly-directed, valinomycin-mediated (in the absence of $\mathrm{K}^{+}$) potassium diffusion gradient caused no increase of the rates of nitrate uptake at the three $\mathrm{pHs}$. On the other hand, the dissipation of $\Delta \psi$ by the addition of valinomycin in the presence of $\mathrm{K}^{+}$resulted in a modest stimulation of the rates of nitrate uptake at the three pHs assayed (Table 3). Taken together, these results indicated that $\Delta \psi$ constituted little or no contribution for the energization of nitrate uptake in $A$. halophytica.

Effect of external pH on nitrate uptake The data presented above indicate that the main driving force for nitrate uptake was contributed by $\Delta \mathrm{pH}$. We therefore further tested the influence of external $\mathrm{pH}$ on nitrate uptake. Figure 2 shows the uptake of nitrate as a function of time under different $\mathrm{pHs}$ of the assay medium. The uptake of nitrate apparently increased with the increase of the external $\mathrm{pH}$. Within $5 \mathrm{~min}$ nitrate uptake appeared to reach maximum for all $\mathrm{pHs}$ tested. The initial rates of nitrate uptake at $\mathrm{pHs} 5.5,7.0$, and 8.2 were calculated to be $0.63 \pm 0.04,0.84 \pm 0.06$, and $1.16 \pm 0.08$ $\mathrm{mmol} \cdot \mathrm{min}^{-1} \cdot \mathrm{mg}^{-1} \mathrm{Chl}$, respectively.

\section{Discussion}

The results shown in this study clearly indicated that there is energy-dependent nitrate uptake in A. halophytica. The energetic component for nitrate uptake was ascribed to the
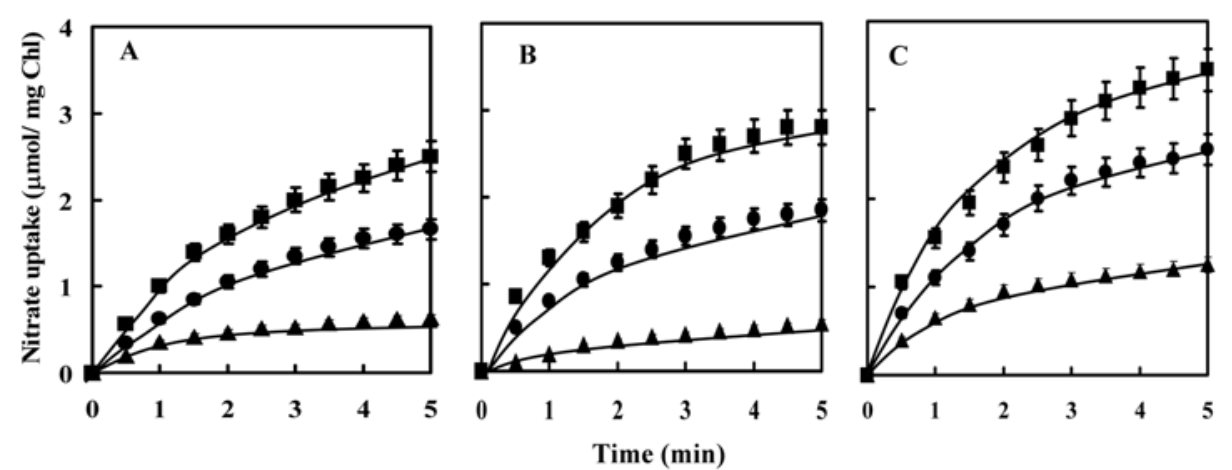

Fig. 1. Effect of $\Delta \mathrm{pH}$ on nitrate uptake at three $\mathrm{pH}$ values of 5.5 (A), 7.0 (B) and 8.2 (C). Artificial generation and suppression of $\Delta \mathrm{pH}$ were done as described in Materials and Methods. Symbols are $\mathbf{O}$ : control, $\boldsymbol{\square}: \Delta \mathrm{pH}$ generation, $\boldsymbol{\Delta}: \Delta \mathrm{pH}$ suppression. Data are means from three independent experiments with vertical bars representing standard errors of the means. 
Table 3. Effect of $\Delta \psi$ on nitrate uptake at different $\mathrm{pHs}^{a}$

\begin{tabular}{|c|c|c|c|c|c|}
\hline \multirow{3}{*}{$\mathrm{pH}$} & \multicolumn{3}{|c|}{ Nitrate uptake $\left(\mu \mathrm{mol} \cdot \mathrm{min}^{-1} \cdot \mathrm{mg}^{-1} \mathrm{Chl}\right)$} & \multicolumn{2}{|c|}{ Nitrate uptake $\left(\mu \mathrm{mol} \cdot \mathrm{min}^{-1} \cdot \mathrm{mg}^{-1} \mathrm{Chl}\right)$} \\
\hline & \multirow{2}{*}{ Control } & \multicolumn{2}{|c|}{$\Delta \psi$ generated by } & \multirow{2}{*}{ Control } & \multirow{2}{*}{$\frac{\Delta \psi \text { dissipated by }}{\text { Valinomycin }\left(+\mathrm{K}^{+}\right.}$} \\
\hline & & $\mathrm{KSCN}$ & Valinomycin $\left(-\mathrm{K}^{+}\right)$ & & \\
\hline 5.5 & $0.79 \pm 0.06$ & $0.71 \pm 0.05$ & $0.78 \pm 0.05$ & $0.84 \pm 0.06$ & $0.92 \pm 0.06$ \\
\hline 7.0 & $0.94 \pm 0.07$ & $0.83 \pm 0.06$ & $0.86 \pm 0.06$ & $0.90 \pm 0.06$ & $0.99 \pm 0.07$ \\
\hline 8.2 & $1.12 \pm 0.08$ & $0.97 \pm 0.07$ & $0.99 \pm 0.07$ & $1.03 \pm 0.07$ & $1.14 \pm 0.08$ \\
\hline
\end{tabular}

${ }^{a}$ For $\mathrm{KSCN}$ and valinomycin $\left(-\mathrm{K}^{+}\right)$experiments, $100 \mathrm{mM}$ Tris-maleate buffer was used at $\mathrm{pH} 5.5$ and $100 \mathrm{mM}$ Tris-HCl buffer was used at $\mathrm{pH} 7.0$ and 8.2. For valinomycin $\left(+\mathrm{K}^{+}\right)$experiments, $100 \mathrm{mM}$ potassium phosphate buffer was used for the three pHs.

Data are means \pm standard errors of the means $(n=3)$.

contribution by the proton motive force $(\Delta p)$ which consists of two components, i. e. the $\mathrm{pH}$ gradient $(\Delta \mathrm{pH})$ and the membrane potential $(\Delta \psi)$ with the relationship, $\Delta \mathrm{p}=\Delta \psi-$ $59 \Delta \mathrm{pH}$, where $\Delta \mathrm{pH}$ equals the $\mathrm{pH}_{\text {out }}$ minus $\mathrm{pH}_{\text {in }}$ (The value 59 is a combination of constants for expression of $\Delta \mathrm{pH}$ in millivolts at $25^{\circ} \mathrm{C}$ ). This conclusion is based on the results showing (i) inhibition of nitrate uptake by various protonophores (Table 1), (ii) an increased nitrate uptake when glucose or lactate was added as an energy source (Table 2).

The data from Fig. 1 show an increase of nitrate uptake upon artificially generating $\Delta \mathrm{pH}$. This increase was observed independent of external $\mathrm{pH}$. On the other hand, the suppression of $\Delta \mathrm{pH}$ always resulted in a significant decrease of nitrate uptake, and again was independent of external $\mathrm{pH}$. This behavior is expected when the $\Delta \mathrm{pH}$ term of the proton motive force is the driving force for nitrate uptake. In contrast to the complete abolition of 4-hydroxybenzoate uptake in Klebsiella planticola strain DSZ1 when $\Delta \mathrm{pH}$ was suppressed (Allende et al., 2002), our results showed some nitrate uptake activity remaining when $\Delta \mathrm{pH}$ was suppressed (Fig. 1). However, this nitrate uptake activity disappeared when $\Delta \mathrm{pH}$ was suppressed in the presence of monensin (data not shown). Thus, it was suggested that $\mathrm{Na}^{+}$-electrochemical gradient dissipated by monensin (Pressman, 1976) was involved in nitrate uptake. The dependence of nitrate uptake on $\mathrm{Na}^{+}$was previously reported in A. halophytica (Incharoensakdi and Wangsupa, 2003). The fact that the protonophores, CCCP, 2, 4-DNP and gramicidin D could not completely inhibit the uptake of nitrate (Table 1) also supports the notion that there exists another energetic component in addition to proton motive force, i. e. the so called sodium motive force which was previously suggested to play a role in nitrate uptake in Anacystis nidulans R2 (Rodriguez et al., 1992; Rodriguez et al., 1994). The contribution by either a proton or a sodium gradient to amino acid and glycine betaine transport has previously been shown in some bacteria (Ekiel et al., 1985; Proctor et al., 1997).

The overall results in Fig. 1 and Table 3 suggest that the uptake of nitrate by $A$. halophytica is driven by $\Delta \mathrm{pH}$. The contribution by $\Delta \psi$ was rather unlikely due to the findings that $\Delta \psi$ generated by either $\mathrm{KSCN}$ or valinomycin in the absence

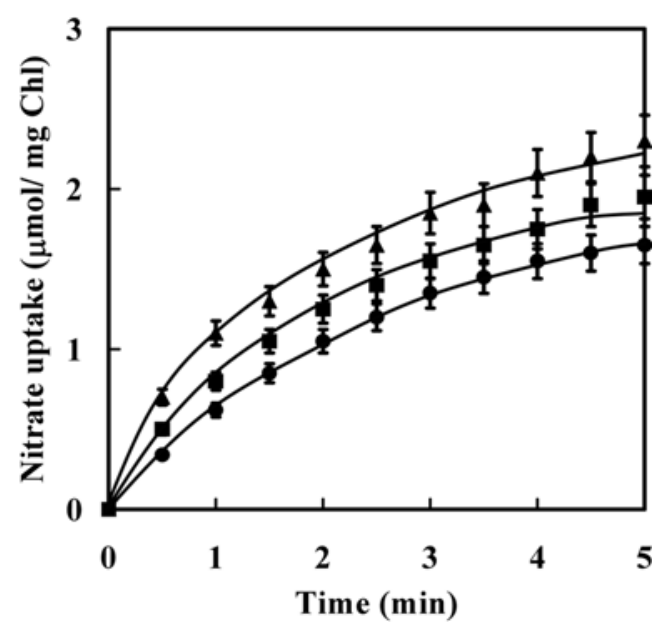

Fig. 2. Dependence of nitrate uptake on external pH. Nitrate uptake assay was done as described in Materials and Methods with the modification where $100 \mathrm{mM}$ Tris-maleate buffer was used at $\mathrm{pH} 5.5(\boldsymbol{O})$ and $100 \mathrm{mM}$ Tris- $\mathrm{HCl} \mathrm{pH} 7.0(\boldsymbol{\square})$ or $\mathrm{pH}$ 8.2 ( $\mathbf{\Delta})$. Data are means from three independent experiments with vertical bars representing standard errors of the means.

of $\mathrm{K}^{+}$had no stimulatory effect on the uptake of nitrate in acidic, neutral, and alkaline conditions (Table 3). Moreover, when $\Delta \psi$ was dissipated by valinomycin in the presence of $\mathrm{K}^{+}$, no depression of nitrate uptake was observed (Table 3). The absence of an inhibitory effect by valinomycin suggests the absence of the contribution of $\Delta \psi$ to nitrate uptake. On the contrary, a slight stimulation of nitrate uptake occurred under the condition depleted of $\Delta \psi$ by valinomycin $\left(+\mathrm{K}^{+}\right)$treatment (Table 3). This stimulation could occur due to (i) the action of $\mathrm{Na}^{+}$-motive force $\left(\mathrm{Na}^{+}\right.$-gradient driven) since valinomycin specifically abolishes $\Delta \psi$ contributed by $\mathrm{K}^{+}$transport (Reed, 1979) and/or (ii) an increase of $\Delta \mathrm{pH}$ term of the proton motive force is generated by a compensatory mechanism, i. e. an increase in $\Delta \mathrm{pH}$ simultaneous to a decrease in $\Delta \psi$ (Reed, 1979; Kroll and Booth, 1981). Similar observations were reported for 4-hydroxybenzoate uptake in Klebsiella planticola whereby $\Delta \mathrm{pH}$ was also implicated as the driving force (Allende et al., 2002). Previously, it was also shown in the cyanobacterium Plectonema boryanum that $\Delta \mathrm{pH}$ is the 
major energetic component with no involvement of $\Delta \psi$ for energy coupling in photosynthesis (Padan and Schuldiner, 1978).

Extracellular $\mathrm{pH}$ also affected the uptake of nitrate in $A$. halophytica. It was shown that raising the extracellular $\mathrm{pH}$ from 5.5 to 8.2 resulted in the enhancement of the rate of nitrate uptake (Fig. 2). The dependence of betaine uptake on the extracellular $\mathrm{pH}$ was previously reported in Lactococcus lactis (Molenaar et al., 1993). However, the increase of the extracellular $\mathrm{pH}$ resulted in the decrease of betaine uptake. This inverse relationship between extracellular $\mathrm{pH}$ and betaine uptake was proposed to be mediated by the intracellular $\mathrm{K}^{+}$ concentration. It is intriguing to speculate that the intracellular $\mathrm{Na}^{+}$might mediate nitrate uptake in response to extracellular $\mathrm{pH}$ in A. halophytica. Previous work has shown that $A$. halophytica contains an $\mathrm{Na}^{+} / \mathrm{H}^{+}$antiporter which can confer salt tolerance on the cells (Waditee et al., 2001; Waditee et al., 2002). Apart from protecting cells against salt stress, $\mathrm{Na}^{+} / \mathrm{H}^{+}$ antiporter can also regulate intracellular $\mathrm{H}^{+}$levels (Padan and Schuldiner, 1996). During the generation of a $\mathrm{pH}$ gradient across the membrane, an increase in the extracellular $\mathrm{pH}$ would lead to a decrease in the $\mathrm{pH}$ gradient and consequently the intracellular $\mathrm{Na}^{+}$might also decrease. The observed increase of nitrate uptake at increasing extracellular $\mathrm{pH}$ (Fig. 2) might be accounted for by an increase of $\mathrm{Na}^{+}$-gradient mediated by $\mathrm{Na}^{+} / \mathrm{H}^{+}$antiporter. Indeed, the activity of $\mathrm{Na}^{+} / \mathrm{H}^{+}$ antiporter in A. halophytica was shown to increase with increasing $\mathrm{pH}$ (Waditee et al., 2001). Moreover, we also observed a reduction of nitrate uptake in A. halophytica in the presence of amiloride, an inhibitor of $\mathrm{Na}^{+} / \mathrm{H}^{+}$antiporter (Mochizuki-Oda and Oosawa, 1985) (data not shown). Thus, the involvement of $\mathrm{Na}^{+} / \mathrm{H}^{+}$antiporter in the uptake of nitrate cannot be precluded. That the role of $\mathrm{Na}^{+} / \mathrm{H}^{+}$antiporter in the generation of sodium motive force to power $\mathrm{Na}^{+}$/ solute symport has previously been proposed for the transport of anions across the membranes (Krulwich and Guffanti, 1989; Espie and Kandasamy, 1994).

The fact that DCCD, the ATPase inhibitor, and the ionophores, CCCP, 2, 4-DNP, and gramicidin D strongly inhibited the uptake of nitrate (Table 1) highly suggests that the energy needed is provided by electron transport in the cytoplasmic membrane through a proton motive force, with the participation of ATP hydrolysis. Previous studies have shown that an ATP-binding cassette (ABC)-type system with the two ATP-binding proteins is involved in nitrate uptake in the cyanobacterium Synechococcus sp. PCC7942 (Omata, 1995). Further work on the characterization of proteins responsible for nitrate uptake in A. halophytica is needed for a better understanding of nitrate uptake in cyanobacteria.

Acknowledgments The financial support from the Thailand Research Fund to A. Incharoensakdi (RSA/4/2543) is gratefully acknowledged. S. Laloknam also thanks the Thailand Research Fund for the support through the Royal Golden Jubilee Ph.D. Program.

\section{References}

Allende, J. L., Gibello, A., Fortun, A., Mengs, G., Ferrer, E. and Martin, M. (2000) 4-Hydroxybenzoate uptake in an isolated soil Acinetobacter sp. Curr. Microbiol. 40, 34-39.

Allende, J. L., Gibello, A., Fortun, A., Sanchez, M. and Martin, M. (2002) 4-Hydroxybenzoate uptake in Klebsiella planticola strain DSZ1 is driven by $\Delta \mathrm{pH}$. Curr. Microbiol. 44, 31-37.

Booth, I. R. (1985) Regulation of cytoplasmic $\mathrm{pH}$ in bacteria. Microbiol. Rev. 49, 359-378.

Crawford, N. M. and Glass, A. D. M. (1998) Molecular and physiological aspects of nitrate uptake in plants. Trends Plant Sci. 3, 389-395.

Ekiel, I., Jarrel, K. F. and Sprot, G. D. (1985) Amino acid biosynthesis and sodium-dependent transport in Methanococcus voltae, as revealed by ${ }^{13} \mathrm{C}-\mathrm{NMR}$. Eur. J. Biochem. 149, 437444.

Espie, G. S. and Kandasamy, R. A. (1994) Monensin inhibition of $\mathrm{Na}^{+}$-dependent $\mathrm{HCO}_{3}^{-}$transport distinguishes it from $\mathrm{Na}^{+}-$ independent transport and provides evidence for $\mathrm{Na}^{+} / \mathrm{HCO}_{3}{ }^{-}$ symport in the cyanobacterium Synechococcus UTEX 625. Plant Physiol. 104, 1419-1428.

Flores, E. and Herrero, A. (1994) Assimilatory nitrogen metabolism and its regulation; in The Molecular Biology of Cyanobacteria, Bryant, D. A. (ed.), pp. 487-517, Kluwer Academic Publishers, Dordrecht, the Netherlands

Garcia-Sanchez, M. J., Jaime, M. P., Ramos, A., Sanders, D. and Fernandez, J. A. (2000) Sodium-dependent nitrate transport at the plasma membrane of leaf cells of the marine higher plant Zostera marina L. Plant Physiol. 122, 879-885.

Incharoensakdi, A. and Waditee, R. (2000) Degradation of glycine betaine by betaine-homocysteine methyltransferase in Aphanothece halophytica: effect of salt downshock and starvation. Curr. Microbiol. 41, 227-231.

Incharoensakdi, A. and Wangsupa, J. (2003) Nitrate uptake by the halotolerant cyanobacterium Aphanothece halophytica grown under non-stress and salt-stress conditions. Curr. Microbiol. 47, 255-259.

Incharoensakdi, A. and Wutipraditkul, N. (1999) Accumulation of glycine betaine and its synthesis from radioactive precursors under salt-stress in the cyanobacterium Aphanothece halophytica. J. Appl. Phycol. 11, 515-523.

Joshi, A. K., Ahmed, S. and Ferro-Luzzi, G. (1989) Energy coupling in bacterial periplasmic transport systems. J. Biol. Chem. 264, 2126-2133.

Kroll, R. G. and Booth, I. R. (1981) The role of potassium transport in the generation of a $\mathrm{pH}$ gradient in Escherichia coli. Biochem. J. 198, 691-698.

Krulwich, T. A. and Guffanti, A. A. (1989) The $\mathrm{Na}^{+}$cycle of extreme alkalophiles: a secondary $\mathrm{Na}^{+} / \mathrm{H}^{+}$antiporter and $\mathrm{Na}^{+} /$ solute symporters. J. Bioenerg. Biomembr. 21, 663-677.

Lara, C., Romero, J. M. and Guerrero, M. G. (1987) Regulated nitrate transport in the cyanobacterium Anacystis nidulans. $J$. Bacteriol. 169, 4376-4378.

Mackinney, G. (1941) Absorption of light by chlorophyll solutions. J. Biol. Chem. 140, 314-322.

Meharg, A. A. and Blatt, M. R. (1995) $\mathrm{NO}_{3}^{-}$transport across the plasma membrane of Arabidopsis thaliana root hairs: kinetic control by $\mathrm{pH}$ and membrane voltage. J. Membr. Biol. 145, 4966. 
Miller, A. J. and Smith, S. J. (1996) Nitrate transport and compartmentation in cereal root cells. J. Exp. Bot. 47, 843-854.

Mochizuki-Oda, N. and Oosawa, F. (1985) Amiloride-sensitive $\mathrm{Na}^{+}-\mathrm{H}^{+}$antiporter in Escherichia coli. J. Bacteriol. 163, 395397.

Molenaar, D., Hagting, A., Alkema, H., Driessen, A. J. M. and Konings, W. N. (1993) Characteristics and osmoregulatory roles of uptake systems for proline and glycine betaine in Lactococcus lactis. J. Bacteriol. 175, 5438-5444.

Omata, T. (1995) Structure, function and regulation of the nitrate transport system of the cyanobacterium Synechococcus sp. PCC 7942. Plant Cell Physiol. 36, 207-213.

Padan, E. and Schuldiner, S. (1996) Bacterial $\mathrm{Na}^{+} / \mathrm{H}^{+}$antiporters: molecular biology, biochemistry, and physiology; in Handbook of Biological Physics, Konings, W. N., Kaback, H. R. and Lolkema, J. S. (eds.), pp. 501-531, Elsevier Science, Amsterdam, the Netherlands.

Padan, E. and Schuldiner, S. (1978) Energy transduction in the photosynthetic membranes of the cyanobacterium Plectonema boryanum. J. Biol. Chem. 253, 3281-3286.

Pressman, B. C. (1976) Biological application of ionophores. Аnnu. Rev. Biochem. 45, 501-530.

Proctor, L. M., Lai, R. and Gunsalus, R. P. (1997) The methanogenic archaeon Methanosarcina thermophila TM-1 possesses a high affinity glycine betaine transporter involved in osmotic adaptation. Appl. Environ. Microbiol. 63, 2252-2257.

Reed, P. W. (1979) Ionophores. Meth, Enzymol. 55, 435-454.

Rodriguez, R., Guerrero, M. G. and Lara, C. (1994) Mechanism of sodium/ nitrate symport in Anacystis nidulans R2. Biochim. Biophys. Acta. 1187, 250-254.

Rodriguez, R., Lara, C. and Guerrero, M. G. (1992) Nitrate transport in the cyanobacterium Anacystis nidulans R2: kinetic and energetic aspects. Biochem. J. 282, 639-643.

Takabe, T., Incharoensakdi, A., Arakawa, K. and Yokota, S. (1988) $\mathrm{CO}_{2}$ fixation and RuBisCO content increase in a highly halotolerant cyanobacterium Aphanothece halophytica, grown in high salinity. Plant Physiol. 88, 1120-1124.

Waditee, R., Hibino, T., Nakamura, T., Incharoensakdi, A. and Takabe, T. (2002) Overexpression of $\mathrm{Na}^{+} / \mathrm{H}^{+}$antiporter confers salt tolerance on a fresh water cyanobacterium, making it capable of growth in sea water. Proc. Natl. Acad. Sci. USA 99, 4109-4114.

Waditee, R., Hibino, T., Tanaka, Y., Nakamura, T., Incharoensakdi, A. and Takabe, T. (2001) Halotolerant cyanobacterium Aphanothece halophytica contains an $\mathrm{Na}^{+} / \mathrm{H}^{+}$antiporter, homologous to eukaryotic ones, with novel ion specificity affected by C-terminal tail. J. Biol. Chem. 276, 36931-36938. 